\title{
Economics of Wheat Breeding Strategies: Focusing on Oklahoma Hard Red Winter Wheat
}

\author{
Jeffrey Vitale ${ }^{1, *}$, Brian Adam ${ }^{1}$ and Pilja Vitale ${ }^{2}$ \\ 1 Department of Agricultural Economics, Oklahoma State University, Stillwater, OK 74078, USA; \\ brian.adam@okstate.edu \\ 2 Division of Business, Northern Oklahoma College, Tonkawa, OK 74653, USA; pilja.vitale@noc.edu \\ * Correspondence: jeffrey.vitale@okstate.edu; Tel.: +1-405-744-6175
}

Received: 20 January 2020; Accepted: 25 January 2020; Published: 5 February 2020

\begin{abstract}
Wheat breeding continues to be an important component of agricultural innovations in the Great Plains region of the US. This paper reviews Oklahoma's wheat breeding program over the past several decades with an emphasis on the economic aspects and planning of future breeding strategies. Over the past century, Oklahoma's wheat yields have increased but the productivity gains have been offset in part due to increased yield variability. The shift to improved wheat varieties has resulted in increased susceptibility to plant disease and pest pressure. While a few varieties introduced over the past few decades have dominated the wheat seed market, recent trends indicate producers are adopting a more diverse range of wheat varieties. Producers' concerns have expanded beyond demands for high yielding varieties to include more market oriented needs to increase protein content and test weight. This paper identifies several key policy instruments that Oklahoma stakeholders and policy makers should consider when planning future breeding strategies. A critical need is to assist Oklahoma producers in adapting to climate change by developing drought and heat resistant wheat varieties. Marketing new varieties would be improved and revenue increased if more innovative pricing structures were adopted to better align producers' willingness to pay with seed development costs, which could then be re-invested in breeding. Research budgets, which have remained stagnant in real terms, will need to be increased to adequately address producers' needs into the 21st century.
\end{abstract}

Keywords: wheat varieties; seed; wheat breeding

\section{Introduction}

Wheat is one of the main staple foods for feeding human populations throughout the world [1]. Global wheat demand is expected to increase by an estimated 70 percent over the next few decades (2020-2050) as human population pressure and rising income levels dramatically increase household consumption [2]. Generating an adequate supply response will remain a policy challenge well into the 21st century [3]. Even with anticipated productivity gains from the introduction of new technology, future wheat supply will have difficulty keeping pace with demand due to external factors such as climate change and shifts in consumer preferences towards starch based foods [4-7]. The prolonged growing season of winter wheat makes it particularly susceptible to climate change through increased exposure to extreme weather events. In the Southern Plains of the US, additional freezing episodes in the fall, and winter and greater heat stress in the summer, are expected to have an overall negative effect on wheat yield [8].

Increasing wheat yields over the coming decades is hence one of the most important goals for current agricultural policy to assure future generation's consumption needs are satisfied. Increasing wheat yields will require improving farm production systems and introducing new technology, developing improved wheat varieties, identifying optimal crop rotation and diversification strategies, 
improving plant protection, and continued support from stakeholders throughout the value including technology providers, processors, manufacturers, and governments [9-11]. Developing improved wheat varieties is largely the responsibility of wheat breeders, whose role in improving crop productivity continues to grow in significance over time [12]. The objectives of this paper are to present a review of the wheat breeding program in Oklahoma: (1) explore the historic role that wheat breeding has played in developing new wheat varieties in Oklahoma, (2) review current wheat breeding program and strategies, (3) provide an outlook of the future needs and requirements of Oklahoma's wheat breeding program from an economic perspective, and (4) suggest future wheat breeding strategies to meet 21st century needs.

\section{Wheat Production and Breeding in Oklahoma: Past and Present}

Wheat production has been an important part of Oklahoma's history dating back to its territorial period during the US land expansion of the 19th century. Winter wheat (Triticum aestivum L.) has been the dominant type of wheat produced in Oklahoma over the past century. The following describes the linage of Oklahoma's wheat production since statehood in 1912.

\section{Wheat Yield, Planted Acreage, and Production}

Oklahoma wheat yields have increased significantly (329 percent) over the past century, from a time-trend average of $7.9 \mathrm{bu} / \mathrm{acre}$ in 1895 to $33.9 \mathrm{bu} / \mathrm{acre}$ in 2018 (Figure 1). The large yield increase is explained by the development of modern farming techniques and advances in breeding compared to traditional farming methods and wheat varieties utilized at the turn of the 20th century. Recent trends, however, show that the long-term trend in increased wheat yields has been accompanied by substantial yield variation (Figure 1). Since 1981, annual inter-year yield variation has continued to widen, reaching its largest ever proportion over the past few years. Yield variability introduces risk into producers' decision making criteria, resulting in a shift to more stable yet typically less profitable farm enterprises [13]. Reducing yield variability has been one of the most important objectives for wheat producers and is expected to remain at the forefront of the wheat breeding research agenda, since climate change is expected to greatly exacerbate yield variability $[14,15]$. Wheat breeding will hence need to explicitly address future climatic forecasts in developing varieties to better tolerate hotter, drier conditions that are expected to prevail well into the 21st century $[5,8,14,16-21]$.

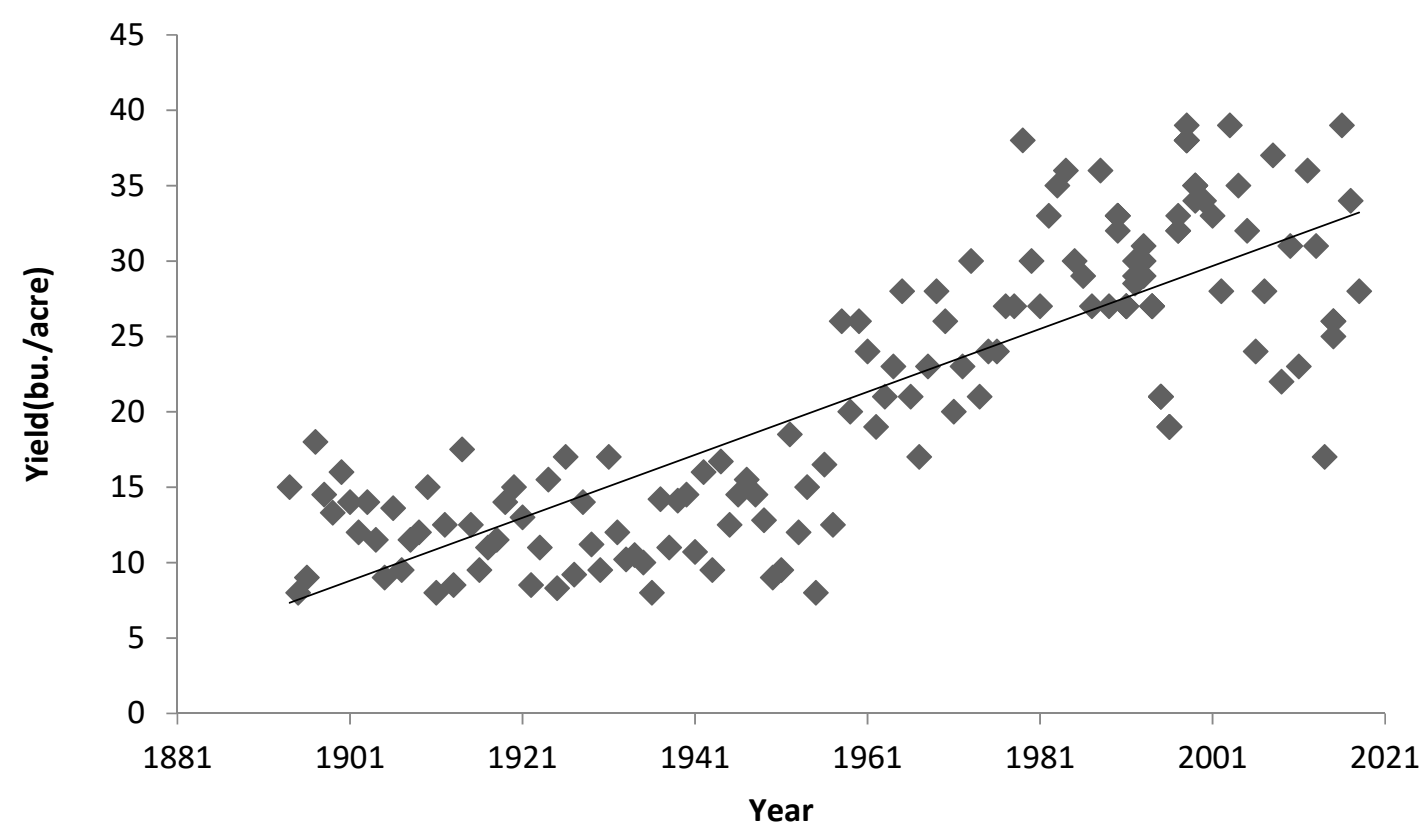

Figure 1. Wheat yields in Oklahoma from 1881 to 2018. Source: USDA-NASS Quickstats (2018) [22]. 
Oklahoma's wheat planted acreage has decreased substantially since 1990 (Figure 2). In large part, the area decline can be explained by decreasing returns per acre from downward long-term price trends. Rival crops that compete with wheat for farmland have better weathered long-term price declines and have experienced greater productivity growth, e.g., soybeans, corn, and sorghum [23]. Government policy has also contributed to decreased wheat acreage [24]. In 1996, newly enacted "Freedom to Farm" laws removed base acreage requirements for government farm payments, reducing incentives for planting wheat $[25,26]$. The mid 90 s shift to more liberal policies, enabling producers to increase returns by shifting to alternative crops such as sorghum and millet, had thus an unintended consequence of reducing wheat acreage.

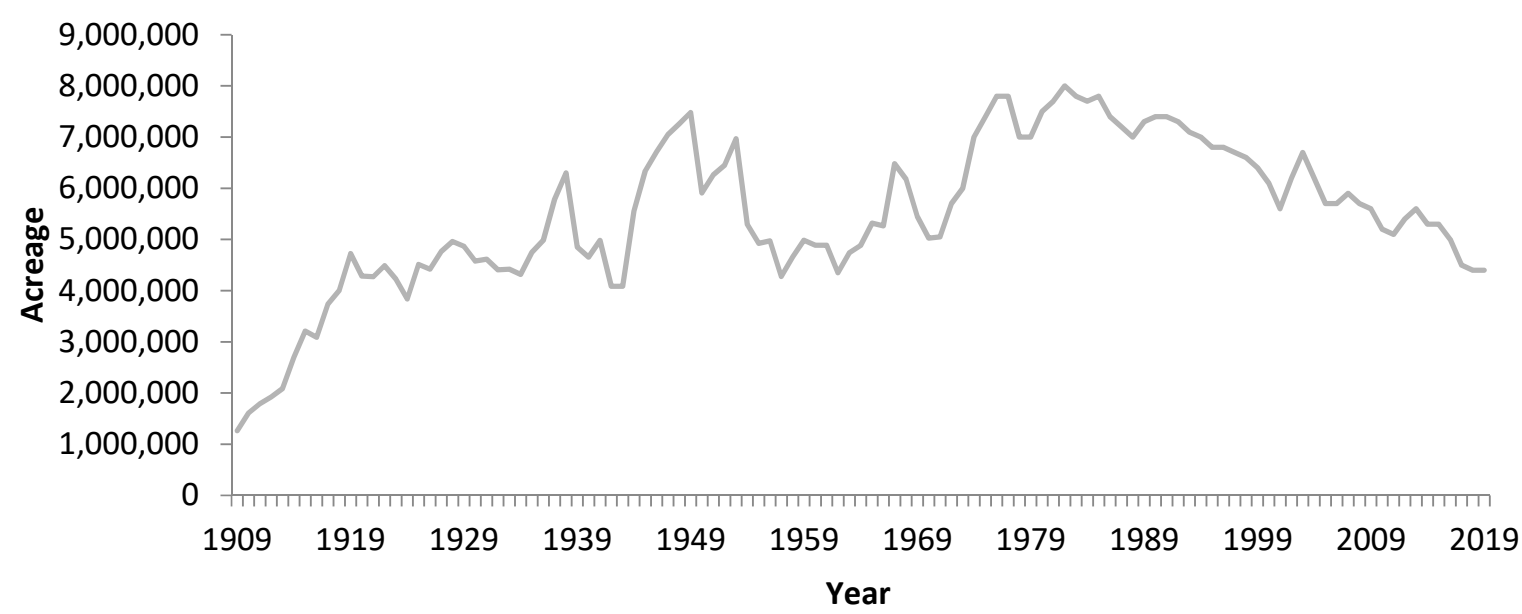

Figure 2. Wheat planted acreage in Oklahoma from 1909 to 2018. Source: USDA-NASS Quickstats 2018 [22].

The ongoing decline of wheat acreage indicates a need to increase demand for wheat based products, including a shift towards developing premium wheat products that can compete with rival crops and emerging health food trends such as local foods and organically grown crops. Over the past couple of decades, US per capita consumption of both soft and hard wheat has declined by $9.4 \%$ due to perceived health concerns from gluten based products, including obesity and links to celiac disease $[27,28]$. Recent studies have argued, however, that obesity cannot be directly linked to any particular food, rather it is a general outcome of inactive lifestyles and overeating [29]. The negative trends in wheat consumption could be reversed if consumer perceptions were reshaped by information campaigns that raised awareness over the benefits of a health-conscious whole wheat diet that has been associated with significant reductions in risks for obesity related diseases such as type 2 diabetes and heart disease [29]. Such public awareness by the wheat industry should refute claims that modern genetic research has created an unnatural protein (gliadin) that promotes obesity by stimulating appetite, resulting in increased caloric consumption [30,31].

\section{Main Findings: Oklahoma's Legacy of Wheat Varieties}

Oklahoma wheat producers have adopted new wheat varieties in an ongoing basis over the past several decades. The following is a review of the legacy of wheat varieties that have been developed over the past century.

\subsection{History and Current Status of Oklahoma's Wheat Varieties}

In its formative years of agriculture at the turn of the 20th century, Oklahoma's producers grew several wheat varieties. The more popular of the varieties grown during the formative period were brought to the US by European immigrants, primarily German Mennonites, who settled in the newly opened frontier lands of the US Great Plains [18,32]. As research and development grew in significance 
with the 1897 Hatch Experiment Station Act, agronomists identified a handful of the more promising wheat varieties. The awkwardly named Turkey variety, which actually originates from Russia, quickly became the region's dominant wheat variety [33-35]. By the end of World War I, Turkey had become the most popular variety and stayed so during the following couple of decades, 1920-1940 (United States Department of Agriculture-USDA 2012, USDA 2018). When Turkey was the most dominant wheat variety planted, it was planted on the majority of Oklahoma's wheat acres (70 percent).

Following Turkey's popularity in the early decades of the 20th century, the Triumph series became the dominant wheat variety in Oklahoma following the end of World War II until the 1980s [36,37] (USDA 2012, USDA 2018). Triumph reached its maximum adoption in 1964, when nearly two-thirds of Oklahoma's wheat acreage (65 percent) was planted in Triumph [36,37] (USDA 2012, USDA 2018). It continued as one of Oklahoma's most enduring wheat varieties, remaining in active use as late as 2004 (0.3 percent). A third wheat variety, Jagger, became the region's dominant wheat variety throughout the 1990s and into the first decade of the 21st century [36,37] (USDA 2012, USDA 2018). At its peak, Jagger occupied nearly half of Oklahoma's wheat acreage (42.3 percent) in 2004. While other varieties have since surpassed its popularity, Jagger is still planted on Oklahoma wheat farms up to the present day.

Those popular varieties (Turkey, Triumph, and Jagger) represented traditional breeding objectives for the Great Plains, i.e., high yielding varieties that are well suited for dual purpose wheat [38]. Over the past couple of decades, however, a wider range of wheat varieties have been developed to address specialized needs of producers. Gallagher, for example, is a high yielding variety suitable for dual purpose wheat and was specifically bred for Hessian fly (HF) resistance by Oklahoma Genetics, Inc. [39]. Gallagher has been one of the most popular varieties over the recent past. In 2019, Gallagher was planted on 19.8 percent of Oklahoma's wheat acreage [36,37] (USDA 2012, USDA 2018). Duster has been another popular variety, although over the past few years it has lost its market share, declining from 14.1 to 2.6 percent over the five-year period from 2015 to 2019 [27,40] (USDA 2019, OSU 2019). Most of Duster's lost market share is due to its inferior milling and baking quality compared to Gallagher [41].

The relatively low market share of the most popular varieties over the past couple of decades is explained by recent trends in wheat production and the increased number of new varieties available for producers to address specific needs. Prior to the 20th century, one wheat variety dominated market share with overall shares ranging between 30-70 percent of planted area. However, with the recent trends in more specialized breeding, no single wheat variety has been able to capture seed markets with the same level of dominance occupied by previous varieties (Turkey, Triumph, and Jagger). Dominant varieties in today's markets occupy typically less than 20 percent of the seed market, with a collection of other less known and/or specialized wheat varieties occupying between 30 to 40 percent of market share. Such recent trends illustrate how wheat varieties are continually diversified by breeders to satisfy specific producer needs.

\subsection{Oklahoma's Wheat Breeding Institutions: Contemporary Strategies and Perspectives}

Recent trends in breeding strategies targeting specialized needs of producers have generated a diverse portfolio of wheat variety options. Oklahoma's wheat producers can now choose from dozens of wheat varieties from both the public and private sector (Table 1). The predominant type wheat remains hard red winter wheat, which is grown on virtually all of Oklahoma's acreage (97.1 percent), with the remaining acreage (2.9 percent) in soft red winter wheat (Table 1). Public seed companies have an overwhelming market share among identified winter wheat varieties, accounting for 78.6 percent of identified seed sales in the 2019 production season (Table 1). The private seed market is noticeably smaller, comprising a 21.4 percent market share of identified seed sales in 2019 (Table 1). Over the past few years, the most popular varieties, by planted acres, were released by the Oklahoma State University (OSU) breeding program, accounting for 69.9 percent of identified seed sales in the 2019 production season (Table 1). This punctuates the successful breeding program established by OSU and 
reinforces the importance of maintaining adequate public investments in wheat breeding in the Great Plain states, such as Oklahoma, which combine to form the major wheat producing region in the USA.

Table 1. Oklahoma hard red wheat variety Planted by Institution: 2019 production season.

\begin{tabular}{|c|c|c|c|}
\hline Sector & Institution $^{1}$ & Wheat Type & $\begin{array}{c}\text { Planted Acreage } \\
\text { (Percent) }\end{array}$ \\
\hline \multirow[t]{3}{*}{ Public } & OSU & Hard red & 43.3 \\
\hline & TAM & "..." & 3.1 \\
\hline & KSU & “..." & 2.5 \\
\hline \multirow[t]{3}{*}{ Private } & WB & “..." & 7.5 \\
\hline & SY & “..." & 4.9 \\
\hline & LCS & “..." & 0.9 \\
\hline Not Specified & Not Specified & Hard (various types) ${ }^{2}$ & 4.6 \\
\hline “..." & “..." & $\begin{array}{l}\text { Hard (unidentified } \\
\text { names and type) }\end{array}$ & 29.2 \\
\hline “...” & “..." & Soft (various types) 4 & 3.0 \\
\hline Total & & & 100.0 \\
\hline
\end{tabular}

${ }^{1}$ OSU refers to Oklahoma State University, TAM to Texas A\&M University, KSU to Kansas State University, WB to Westbred Company, SY to Syngenta, and LCS to Limagrain Cereal Seeds. ${ }^{2}$ Hard winter wheat in this category contains various varieties from either the public or private sector and originating from other institutions. ${ }^{3}$ Hard winter wheat in this category contains unknown varieties from either the public or private sector and from unidentified institutions. ${ }^{4}$ Soft wheat in this category is from an unidentified sector and institution. Source: USDA-NASS Oklahoma Wheat Variety Report, April 2019 [40].

Private companies have been less responsive to the needs of wheat producers in the Great Plains. The limited interest of the private sector is likely due to the lower returns from the wheat seed industry compared to the more lucrative corn, soybean, and cotton seed markets. In particular, genetically modified corn, soybean, and cotton have preoccupied the major seed companies over the past couple of decades, crowding out investments in wheat seed R\&D. As a result, the adoption and uptake of wheat varieties from the private sector lag varieties released from the public domain. In 2019, Oklahoma's wheat had only 13.3 percent of its total wheat acres planted in varieties released by private companies (Table 1).

Oklahoma's wheat breeding program has traditionally targeted developing high yielding varieties [42,43]. The impact of Oklahoma's breeding strategies targeting high yielding wheat varieties has been substantial, contributing in large measure to the three-fold wheat yield increase Oklahoma has experienced over the past century (Figure 1). The importance of cattle production in the mixed farming systems employed by most of Oklahoma's producers has led to the development of varieties that perform optimally as dual purpose wheat [44]. Oklahoma is one of the largest cattle producers in the US, and most wheat producers also produce cattle. Substantial co-benefits are generated from dual purpose wheat, i.e., producing wheat as both a forage, prior to first hollow-stem development, and as a revenue producing crop through subsequent grain harvest.

Over time, breeding has evolved in response to increased pest and weed pressure by introducing varieties resistant to insects such as greenbug (GB), HF, and Russian wheat aphid (RWA) [45-47]. The prevalence of foliar diseases in Oklahoma's wheat production has been addressed though the development of cultivars with increased resistance to wheat rust and mildew related diseases [48].

OSU wheat breeders have focused on a variety of crop management and agronomic constraints of wheat producers in their state, e.g., nutrient efficiency, drought management, and crop rotation $[44,46,48,49]$. Other winter wheat varieties have addressed weed pressure additional agronomic issues such as awn suppression and increasing coleoptile length [50-52].

\subsubsection{Environmental Issues: Adaptation to Local Conditions}

Societal concerns on protecting the environment have led to an awareness among all agricultural stakeholders to promote the prudent use of inputs, particularly environmentally sensitive inputs, 
which leave large carbon footprints or degrade flora and fauna in sensitive ecosystems [53-57]. An objective of Oklahoma's breeding over the past few decades has been to maximize crop efficiency by matching plant growth characteristics and performance to local environmental conditions. Achieving such peak efficiency requires developing varietal lines that require the minimal use of water, soil preparation, fertilizers, chemicals, and other inputs while maintaining production performance standards [58]. Drought avoidance and tolerance has also been a targeted objective of Oklahoma's breeding strategies given the low rainfall conditions that prevail throughout much of the state [52].

Breeders often focus on developing varieties that are the most nitrogen efficient $[49,59,60]$. Addressing nitrogen has co-benefits to both producers through reduced fertilizer costs and the environment through less runoff into local watersheds. Modern advances in crop genetics enable breeders to utilize biotechnology, such as molecular markers, to identify existing varieties that are well adjusted to local conditions by scoring their performance based input and output efficiency measures. Based on recent USDA data, in the major Oklahoma wheat producing regions (Panhandle, Northeast, other Northcentral districts), circa 50 percent of wheat was planted in local varieties that had no commercial attachment. This illustrates the extent to which producers in many areas of the state do not use well known commercial varieties, i.e., those developed by either public or private institutions. Such areas could provide future opportunities to apply genetic engineering tools to improve crop efficiency, promote improved environmental stewardship, and address climate change concerns.

\subsubsection{Milling, Processing, and Consumer Oriented Issues in Selective Breeding Strategies}

The primary use of wheat throughout most of the world, including in the US, is providing staple and other baked foods such as breads, pastas, cakes, and snack items. Millers and bakers are thus the main purchasers of wheat at the farm gate, whereas end users of wheat are consumers of bread and other wheat products. Through purchasing power, consumers typically have the loudest voice when determining taste, nutritional, and other characteristics of wheat. US wheat, including Oklahoma wheat, has been consumed in both domestic and international markets. In 2014, domestic use was 47 percent while international use was 53 percent [61]. Domestic demand has remained more or less stable but has experienced modest declines based on population changes and consumer preferences. Like most staple foods, wheat has been less responsive to wheat prices and household incomes. Recent domestic wheat demand is declining due to consumer awareness of gluten free foods and low-carbohydrate diets. Most of US wheat has been used in bread flour, which has declined in demand, although exports from world wheat demand have increased. Wheat breeders and policy makers should be aware of recent trends in domestic consumer demand. New breeding efforts could be designed to provide a healthier perception of wheat and develop a more diversified line of wheat varieties that can provide flours better adapted to a wider range of foods appealing to more lifestyles, such as noodles, pasta, and tortillas.

An emerging trend over the past decade is the growth of niche (specialized) markets that satisfy the parochial needs of wheat producers. Over the past few years, uptake rates of wheat varieties in niche markets have increased by almost 10 percent in Oklahoma. Recent breeding has responded by addressing traits and characteristics to satisfy consumer preferences and market demands on wheat quality, including mill-ability, bake-ability, taste and texture characteristics, and optimizing protein content [62-64]. This trend towards niche varieties is in response to wheat producers shifting preferences toward varieties that have been adapted to local conditions through significant input from wheat producers familiar with regional constraints. This trend will likely continue for the next few years due to the ongoing dynamics in pest and disease pressure on wheat production as well as future challenges from consumers' shifting preferences towards more diverse healthy diets and climate change. This includes prospects for developing varieties more responsive to organic farming methods and other health related production trends. Wheat breeding institutions should continue the trend towards specialization and developing niche varieties by releasing more locally adapted wheat varieties to meet producers' and consumers' ongoing needs specific to sub-regional areas. 


\subsubsection{Oklahoma's Preferences for Wheat Varieties: Great Plains Regional Comparisons}

Preference for high yielding varieties continues to be the most desired trait among Oklahoma winter wheat producers [43]. Compared to other states in the Great Plains, Oklahoma wheat producers have less preference for other traits, such as insect resistance, which often hold the greatest importance in other wheat producing regions [65]. Wheat breeders have developed varietal lines that provide resistance to HF and some biotypes of greenbug (GB) and other pests such as the Russian wheat aphid (RWA) [45-47]. Breeding resistance into varieties is challenging, however, because bio-types with variable levels of virulence exist for both of these aphid species [66-68]. According to farm survey data reported in Table 2, Oklahoma wheat producers adopted the lowest number of insect resistant winter wheat varieties compared to surrounding states in the Great Plains region (Table 2). United States Department of Agriculture (USDA) annual surveys, conducted from 2000 to 2010, found that varieties listed as RWA resistant were seeded on less than 0.1 percent of the wheat acres across the region, with use in Colorado reported at 20 percent. Acreage seeded to varieties listed as GB resistant ranged from 1.1 percent to 5 percent [69]. In Oklahoma, none of its wheat area was planted in GB resistant varieties.

Table 2. Adoption rate (percent of total area) of resistant varieties to aphid by state.

\begin{tabular}{ccccc}
\hline \multicolumn{5}{c}{ Year } \\
\hline State & $\mathbf{2 0 0 2}$ & $\mathbf{2 0 0 3}$ & $\mathbf{2 0 0 4}$ & $\mathbf{2 0 0 5}$ \\
\hline Colorado (CO) & 42.5 & 44.2 & 51.2 & 49.4 \\
Kansas (KS) & 0.0 & 0.0 & 0.0 & 0.0 \\
Nebraska (NE) & 0.7 & 2.2 & 3.1 & 2.2 \\
Oklahoma (OK) & 0.0 & 0.0 & 0.0 & 0.0 \\
Texas (TX) & 27.5 & 39.1 & 38.9 & 31.0 \\
Wyoming (WY) & 0.3 & 2.6 & 10.1 & 1.9 \\
\hline
\end{tabular}

Source: Ph.D. Thesis, Vitale 2013 [65].

\subsection{Future Wheat Breeding Strategies}

Over the last 100 years, wheat has been the most important crop to producers in Oklahoma. Wheat's role has, however, been modestly declining over the recent past. Into the 21st century, the role of wheat will depend on a complex nexus among wheat breeders, producers, and consumers. Breeders will remain challenged to meet the dynamic changes expected in in response to climate change, shifting consumer preferences towards healthy foods, and enabling environmentally friendly production practices. Future breeding can generate substantial productivity gains by catching up to the new technology that row crops such as corn, cotton, and soybean have benefitted from over the past couple of decades. It is also very important to maintain the strong government support that has fostered the Oklahoma wheat industry to date.

\subsubsection{Climate Change and Wheat Variety Development}

Climate change is an increasing concern for sustaining wheat production into the 21st century [4-7]. Wheat is anticipated to be one of the more susceptible food crops, along with potato, to climate change [8]. Winter wheat is produced over an extended agricultural calendar and is exposed to harsh weather conditions from the cold of late fall to heat of early summer. Statistical modeling has determined that winter wheat yields are better explained by extremes of temperature fluctuations rather than average temperatures [8]. Based on historical data, winter wheat yields in the Southern Great Plains have been negatively impacted by higher temperatures, which have risen between $1-2{ }^{\circ} \mathrm{F}$ over the past century [8]. The effect of the higher temperatures, through increased number of extreme daily temperatures, has had an overall negative effect on wheat yields. According to model results, days of either extreme heat (above $34^{\circ} \mathrm{C}$ ) or cold (below $34^{\circ} \mathrm{C}$ ) have significant, negative effects on winter wheat yield estimated at -7.6 percent and -9.0 percent. 
Climate change is expected to primarily impact temperature and precipitation, but in many parts of the world it will also affect humidity and wind. Three climate change models (HadCM3:A2a, B2a, GGa1) predict hotter, drier weather in the Southern Great Plains, with temperatures rising an average of $4.8^{\circ} \mathrm{C}$ along with a $9.0 \%$ decline in precipitation [70]. Using a crop growth simulation model (WEPP), crop yields were found to be positive in two of the three HadCM3 models with increases of 2.7 percent (A2a) and 5.4 percent (GGa1) and a yield declines of -4.7 percent in the B2a model [70]. The positive wheat yield increases in the climate change models are explained by the dramatic increase in $\mathrm{CO} 2$ levels predicated in the A2a and GGa1 models, where $\mathrm{CO}_{2}$ levels were predicted to increase by 148 percent and 80 percent. The climate change analysis presents the potential for unintended optimism for future wheat production, with the possibility of greater $\mathrm{CO}_{2}$ levels offsetting the negative effects of higher temperature and reduced precipitation.

Recent evidence from surveys and interviews suggest that producers consider flexibility in choosing a variety that is best suited to their local condition as the most important option to mitigate climate change $[8,18]$. Currently, Oklahoma wheat breeders are developing varieties for improved drought and heat tolerance with several already released (e.g., Duster, Gallagher, and Lonerider) [71]. Climate change also is expected to bring severe floods, cooler temperatures, and other climatic shocks. Since those conditions cannot be tested in the field, researching such aspects of climate change requires high investments for developing wheat varieties that can adjust to weather shocks and extreme variability including high temperature, strong winds (lodging), dramatic temperature changes, and severe flooding [17]. Oklahoma is fortunate, since harsh weather and climatic variability, including high winds, drought, and winter freezes, have already been incorporated in breeding efforts over the past several decades. Hence, breeders are expected to be able to use existing varietal lines as starting points for a new range of wheat varieties designed specifically for adaptation to climate change. Oklahoma should continue developing a wide scope of new wheat varieties to match future climate change weather scenarios, which are expected to include more extreme events compared to historic weather patterns.

\subsubsection{Selective versus Hybrid Wheat Breeding and Research in Oklahoma}

Wheat breeding began researching hybrid varieties nearly a century ago, following the scientific and agronomic procedures used in developing other hybrids, notably corn [72]. After nearly five decades of research and development, the first hybrid wheat varieties were released by Cargill in the USA and DeKalb in Australia in the early 1980s [73]. Hybrid wheat has continued to be relatively more costly for seed companies to produce compared to other hybrids such as corn, due to genetic differences that make it more difficult to develop sterility and cross pollination that requires additional agronomic management [74]. Due primarily to their relatively higher seed cost and limited yield advantage, hybrid wheat varieties have not been an economical alternative to open pollinated varieties for producers in many parts of the world including the Southern Plains [75].

Biotechnology has been applied for wheat breeding, including molecular genetics and genetic engineering to provide improved variety selection and introduce new plant characteristics [72]. The private sector has pursued biotechnology for wheat and has developed genetically modified (GM) wheat varieties such as Roundup Ready ${ }^{\circledR}$ wheat (RRW) [76]. Analogous to its corn and soybean counterparts, RRW contains a genetic trait making it resistant to glyphosate based herbicides, enabling post emergence weed control. Applications for its commercial release were submitted but eventually withdrawn by Monsanto in 2004 due in part to pressure from anti-GM groups that publicly lobbied against its release [77]. Concerns over its limited profitability, lack of support from producer groups, and segregation issues between GM and non-GM wheat along marketing chains also likely impacted their decision $[77,78]$.

An impediment to biotechnology is the more complex chromosome of modern winter wheat, a complex hexaploid rather than a simple diploid or tetraploid [79]. This chromosomal characteristic has made it more difficult to apply biotechnology to wheat varieties compared to other crops such as corn 
and soybean [79]. Despite greater technological barriers, successful breeding programs such as OSU should continue incorporating biotechnology into their R\&D programs to improve wheat quality into the 21st century, even though genetically modified varieties are not likely to be commercially viable. For example, transgene hybrid-systems, which generate non-GM seed, are being approved for cultivation as non-GMOs in some crops could be applied in wheat [80]. This could include extending research on introducing other GM traits including fusarium resistance, protein enhancements, and drought tolerance, but are yet to be commercially released in the US due in part to the negative perceptions associated with GM labelled foods [77,78].

\section{Marketing, Pricing, and Funding Mechanisms of New Variety Research in Oklahoma}

\subsection{Pricing Mechanisms of New Varieties}

Seed costs contribute a sizeable share of total production costs (Table 3). For an average wheat producer, seed costs account for 12.3 percent of total operating costs and 4.3 percent of total overall costs [27]. In Oklahoma, for example, seed cost was $\$ 11.61$ per acre in 2018 according to [27] reporting from the Prairie Gate region (Table 3). Farmers in Oklahoma typically spend from $\$ 36$ million (grain only) to $\$ 73$ (dual purpose) million on seeds based on 31.3 million planted acres of wheat. The relatively high share of wheat seed costs provides opportunities for the seed industry to developing marketing structures to capture additional value by supplying variety lines that best match producers' willingness to pay.

Table 3. Seed and total cost for wheat.

\begin{tabular}{lcccccc}
\hline & $\mathbf{2 0 1 3}$ & $\mathbf{2 0 1 4}$ & $\mathbf{2 0 1 5}$ & $\mathbf{2 0 1 6}$ & $\mathbf{2 0 1 7}$ & $\mathbf{2 0 1 8}$ \\
\hline Seed cost $(\$)$ & 12.43 & 12.34 & 12.64 & 11.87 & 11.49 & 11.61 \\
Operating costs $^{1}(\$)$ & 112.28 & 111.37 & 101.72 & 94.48 & 93.54 & 94.63 \\
Total cost $(\$)$ & 274.21 & 279.24 & 273.67 & 264.32 & 265.89 & 270.4 \\
\hline
\end{tabular}

1 Operating cost includes direct cost and total cost includes owned labor, and land. Source: USDA-ERS Commodity costs and returns, 2018.

One of the most important seed producers and distributors is Oklahoma Foundation Seed Stocks, which is part of the Oklahoma Agricultural Extension Station and Oklahoma Genetic Inc. Both are non-profit organizations working for the public good on behalf of Oklahoma wheat producers. Since most of the planted seeds in Oklahoma are open pollinated varieties (OPV), once seeds are purchased, producers can in theory recycle varieties for successive crop seasons. To maintain hybrid genetics, however, producers need to purchase new seed stocks every year from certified seed companies. Producers must decide whether it is worth saving on seed cost or whether added cost of hybrid seeds are remunerative. The price of all seeds currently marketed by Oklahoma public seed companies is $\$ 38$ per bushel, irrespective of variety type [81].

When wheat breeders develop new varieties, the range in intensity of research efforts on competing varietal lines results in significantly different R\&D costs. The process of seed production, marketing, and distribution in general has four separate steps according to [82]: (1) plant breeding R\&D, (2) ramping up of seed production, (3) seed conditioning, and (4) seed marketing and distribution. Seed pricing is developed and proportioned according to the preceding four steps. The cost of seed typically consists of a rather generic cost share structure based on prior seed development according to [82]: Plant breeding ( 40 percent), seed production ( 25 percent), seed conditioning ( 15 percent), and marketing and advertising (20 percent). In order to best develop premium seeds, i.e., high quality and performance seeds, seed companies should be able to segment demand and charge higher prices to capture producers with a higher willingness to pay (WTP) for premium seeds. Such added profits could then be used to develop new lines of premium seeds. With existing price schemes, uniform pricing reduces incentives to produce premium seeds, since the demand from producers with higher 
WTP is not adequately met. Such producers end up paying lower prices for seeds of lower quality. More efficient market outcomes would provide premium seeds at higher prices to those producers with higher WTP while supplying standard varietal lines to other producers with more modest WTP.

Policy makers should hence consider providing more flexible pricing in response to overall seed quality and performance. Benefits would be particularly strong in the initial years of releasing new varieties when early adopters, with their high willingness to pay, will support the higher prices. Moreover, opportunities to take greater advantage of segmenting markets are expected to increase over the coming decades. Based on Oklahoma Foundation Seed Stocks (OFSS) data [81], recent demand for new varieties has increased almost twofold compared to a decade ago. Oklahoma wheat variety report (2019) also shows that producers have voiced demands for new varieties in their field on an ongoing annual basis due to the shifting dynamics in weather, pests, disease, and marketing conditions.

\subsection{Releasing Time for a New Variety}

Releasing a wheat variety takes on average about 12 years from its initial development [83]. Years one through four are typically spent on monitoring variety performance, particularly disease resistance, as new varieties can often express unexpected traits when grown under actual conditions. The fifth year usually involves check for drought and shatter tolerance. Year six entails continued monitoring for consistency with previous years. The final few years (7-12) are devoted to fine tuning the variety to local conditions. This includes location specific adjustment tests, i.e., fine tuning the variety to agronomic and climatic conditions specific to regions within the state. To shorten the development time of a variety, breeders identify local varieties that have performed well in Oklahoma. As noted above in Section 3.2.2, many wheat producers continue to plant local varieties on their own farms, which are excellent candidates for developing hybrid genetic lines.

\subsection{Pricing of Improved Wheat Varieties}

Wheat prices differ by production region, much of which can be explained by regional variation in wheat protein content and other quality factors, including test weight. Based on US wheat associates (accessed 4 October 2019), the price of hard red winter wheat differed by 60 cents per bushel $(1 \mathrm{bu}=$ 0.0272 MT at $13.5 \%$ moisture) between the Gulf of Mexico and the Pacific Northwest, with Pacific prices 11 percent higher than in the Gulf [84]. This price difference substantially affects farmers' income by anywhere from $\$ 8400$ to $\$ 16,800$ based on a typical farm size ranging from 500 to 1000 acres harvested. Protein content also has a significant effect on wheat price. Based on protein content varying from 12 to 13 percent, wheat price is positively affected by protein content at a rate of 70 cents per bushel. For example, wheat price is $\$ 0.35$ higher for a wheat content of 12.5 percent compared to 12.0 percent. While producers have typically focused on high yield when selecting varieties, preferences for achieving higher protein content are growing in importance [85]. The premiums attached to higher protein content reflect how improving Oklahoma's wheat quality can translate to consumers' demand for healthier foods, i.e., high protein content, by increasing their willingness to pay (WTP) for wheat based products. The premium paid by consumers for higher protein continent can increase Oklahoma winter wheat producers' income in the range from $\$ 18,200$ to $\$ 36,400$ based on a typical farm planting in the range of 500 to 1000 acres.

To produce a wheat variety with qualities adapted to regional conditions remains a major challenge to breeders even with the advent of modern new technology. The starting point is the selection of the seed and the desired characteristics that will vary substantially by region. Hence, an important step in the breeding process is to identify local seeds with traits similar to the desired traits. USDA has established commercial standards of wheat quality in several classes, including test weight, defects, and other materials [61]. To increase the quality of wheat, variety breeders must develop ways to increase and improve the key testing metrics developed by USDA and those known to be important to producers. 
The challenges facing breeders are well illustrated with the recent efforts to increase protein content [86-88]. Varieties must be well adapted to local environmental factors and conditions to make optimal use of agronomic inputs, including the complex chemical reactions and processes required to transfer nitrogen compounds from the soil into plant based proteins. Producing wheat with high content of protein hence requires a well-established growing environment, including $\mathrm{N}$ fertility and adequate soil moisture [85]. In nearly any breeding program, an important objective is increasing yield. As breeding has shown, there is a trade-off between increasing wheat yield versus increasing protein content [89]. This indicates that developing high yield varieties can deviate from high wheat quality of wheat and vice-versa. Developing varieties that can achieve both higher yields and maintain, or even increase, protein content is an ongoing challenge for wheat breeders to focus their research efforts.

\subsection{Financing and Budgeting of Oklahoma's Wheat Breeding Program}

The OSU wheat breeding program has been the most important wheat breeding institution in Oklahoma. Its annual budget for improving wheat varieties has been less than $\$ 1$ million over the past few years. Most of its funding comes from the Oklahoma Wheat Commission and the Oklahoma Wheat Research Foundation. Compared to the key role of wheat in Oklahoma, the budget of wheat research is perhaps too small. Given that the value of wheat production is typically in the range of $\$ 380$ million, R\&D spending is less than 0.2 percent of Oklahoma's statewide wheat value. Policy makers should consider leveraging further $R \& D$ funds to address the future concerns over climate change and to provide producers with wheat varieties that satisfy shifting consumer preferences towards healthier foods.

\section{Conclusions}

Wheat has been one of the most important crops in Oklahoma and a key economic asset in rural areas. Concerns over its future viability have been growing. Acreage planted in wheat has declined due to its low economic returns as yield increases have been unable to keep pace with the substantial long-term downward trends in wheat prices. Government flexibility in farm programs, i.e., the removal of base acres during the mid-1990s, accelerated wheat acreage decline.

The future viability of Oklahoma's wheat industry will depend in large part on the continued success of its breeding program. Over the past 100 years, through successive breeding, Oklahoma's wheat yields have increased significantly. In its formative years, a single wheat variety dominated the seed market typically over a span of 10 to 20 years. The reliance on a monolithic variety was in large part due to breeding's priority for developing high yielding wheat varieties. Increasingly, producers are demanding a wider range of characteristics, including higher test weights, increased protein content, and an increasing role of local varieties.

With rising concerns over climate change and its expected effect on weather volatility, future breeding efforts will need to identify varieties that can provide more stable production outcomes. This will be a particular challenge, since the higher yields achieved by breeding new varieties was accompanied by added yield uncertainty. Future breeding planning will need to address other issues from climate change, including pest and weed resistant varieties.

Wheat breeders and policy makers should consider seeking alternative funding sources, including through the private sector. The wheat seed industry in Oklahoma generates revenue of about \$30-70 million per year, strengthened by the prevalence of dual purpose wheat, which requires more seed, about 50 to 100 percent more compared to grain only wheat. Budget shares of total seed market values appear rather modest, as annual R\&D budgets total less than $\$ 1$ million. Through innovative marketing strategies, the Oklahoma seed industry could increase revenue by capturing the stronger demand from wheat producers with higher willingness to pay for improved varieties. By developing a range of premium seed products and segmenting the seed market, the seed industry would be able to capture such premiums. To maintain a dominant position of wheat's economic role for 100 years, state and 
federal governments, wheat producers, and industry stakeholders should continue to support wheat breeding efforts, which has been an important cornerstone of wheat production's success in Oklahoma.

Author Contributions: Conceptualization, B.A.; methodology, P.V. and J.V.; writing-original draft preparation, J.V. and P.V.; writing-review and editing, J.V. and B.A.; supervision, B.A. All authors have read and agreed to the published version of the manuscript.

Funding: Funding for the research was provided in part by the U.S. Department of Agriculture Project 0500-00044-012-00D and Hatch Grant OKL02948.

Acknowledgments: Authors sincerely appreciate the comments and suggestions made by the three reviewers that contributed greatly to this this article.

Conflicts of Interest: The authors declare no conflict of interest.

\section{References}

1. Shiferaw, B.; Smale, M.; Braun, H.-J.; Duveiller, E.; Reynolds, M.; Muricho, G. Crops that feed the world 10. Past successes and future challenges to the role played by wheat in global food security. Food Security 2013, 5, 291-317. [CrossRef]

2. Rosegrant, M. Ag Economic Keynote. In Proceedings of the Ag Innovation Showcase, St. Louis, MO, USA, 23-24 May 2011.

3. Röder, M.; Thornley, P.; Campbell, G.; Bows-Larkin, A. Emissions associated with meeting the future global wheat demand: A case study of UK production under climate change constraints. Environ. Sci. Policy 2014, 39, 13-24. [CrossRef]

4. Lobell, D.B.; Schlenker, W.; Costa-Roberts, J. Climate trends and global crop production since 1980. Science 2011, 333, 616620. [CrossRef] [PubMed]

5. Ortiz, R.; Sayre, K.D.; Govaerts, B.; Gupta, R.; Subbarao, G.V.; Ban, T.; Hodson, D.; Dixon, J.M.; Ortiz-Monasterio, J.I.; Reynolds, M. Climate change: Can wheat beat the heat? Agric. Ecosyst. Environ. 2008, 126, 46-58. [CrossRef]

6. Nelson, G.C.; Rosegrant, M.W.; Palazzo, A.; Gray, I.; Ingersoll, C.; Robertson, R.; Tokgoz, S.; Zhu, T.; Sulser, T.B.; Ringler, C. Food Security, Farming, and Climate Change to 2050: Scenarios, Results, Policy Options; Intl Food Policy Res Inst: Washington, DC, USA, 2010; Volume 172.

7. Semenov, M.A.; Shewry, P.R. Modelling predicts that heat stress, not drought, will increase vulnerability of wheat in Europe. Sci. Rep. 2011, 1, 66. [CrossRef] [PubMed]

8. Tack, J.; Barkley, A.; Nalley, L.L. Effect of warming temperatures on US wheat yields. Proc. Natl. Acad. Sci. USA 2015, 112, 6931-6936. [CrossRef]

9. Gan, Y.T.; Miller, P.R.; McConkey, B.G.; Zentner, R.P.; Stevenson, F.C.; McDonald, C.L. Influence of diverse cropping sequences on durum wheat yield and protein in the semiarid northern Great Plains. Agron. J. 2003, 95, 245-252. [CrossRef]

10. Hawkesford, M.J.; Araus, J.-L.; Park, R.; Calderini, D.; Miralles, D.; Shen, T.; Zhang, J.; Parry, M.A.J. Prospects of doubling global wheat yields. Food Energy Security 2013, 2, 34-48. [CrossRef]

11. Vitale, P.P.; Vitale, J.; Epplin, F. Factors affecting efficiency measures of western great plains wheat dominant farms. J. Agric. Appl. Econ. 2019, 51, 69-103. [CrossRef]

12. Reynolds, M.; Foulkes, J.; Furbank, R.; Griffiths, S.; King, J.; Murchie, E.; Parry, M.; Slafer, G. Achieving yield gains in wheat. Plant Cell Environ. 2012, 35, 1799-1823. [CrossRef]

13. van Winsen, F.; de Mey, Y.; Lauwers, L.; Van Passel, S.; Vancauteren, M.; Wauters, E. Determinants of risk behaviour: Effects of perceived risks and risk attitude on farmer's adoption of risk management strategies. J. Risk Res. 2016, 19, 56-78. [CrossRef]

14. Dixon, J.; Braun, H.-J.; Kosina, P.; Crouch, J.H. Wheat Facts and Futures 2009; Cimmyt: Mexico, Mexico, 2009.

15. Carew, R.; Smith, E.G.; Grant, C. Factors Influencing Wheat Yield and Variability: Evidence from Manitoba, Canada. J. Agric. Appl. Econ. 2009, 41, 625-639. [CrossRef]

16. Habash, D.Z.; Kehel, Z.; Nachit, M. Genomic approaches for designing durum wheat ready for climate change with a focus on drought. J. Exp. Bot. 2009, 60, 2805-2815. [CrossRef] [PubMed]

17. Semenov, M.A.; Halford, N.G. Identifying target traits and molecular mechanisms for wheat breeding under a changing climate. J. Exp. Bot. 2009, 60, 2791-2804. [CrossRef] 
18. Olmstead, A.L.; Rhode, P.W. Adapting North American wheat production to climatic challenges, 1839-2009. Proc. Natl. Acad. Sci. USA 2011, 108, 480-485. [CrossRef]

19. Morgounov, A.; Haun, S.; Láng, L.; Martynov, S.; Sonder, K. Climate change at winter wheat breeding sites in central Asia, eastern Europe, and USA, and implications for breeding. Euphytica 2013, 194, 277-292. [CrossRef]

20. Lopes, M.S.; El-Basyoni, I.; Baenziger, P.S.; Singh, S.; Royo, C.; Ozbek, K.; Aktas, H.; Ozer, E.; Ozdemir, F.; Manickavelu, A. Exploiting genetic diversity from landraces in wheat breeding for adaptation to climate change. J. Exp. Bot. 2015, 66, 3477-3486. [CrossRef]

21. Reynolds, M.; Tattaris, M.; Cossani, C.M.; Ellis, M.; Yamaguchi-Shinozaki, K.; Saint Pierre, C. Exploring genetic resources to increase adaptation of wheat to climate change. In Advances in Wheat Genetics: From Genome to Field; Springer: Tokyo, Japan, 2015; pp. 355-368.

22. USDA-NASS. Quick Stats; United State Department of Agriculture-National Agricultural Statistics Service: Washington, DC, USA, 2018.

23. Oklahoma Wheat Variety Report, April 2019, Agriculture-NASS; United State Department of Agriculture-NASS: Oklahoma City, OK, USA, 2019.

24. Fausti, S.W. The causes and unintended consequences of a paradigm shift in corn production practices. Environ. Sci. Policy 2015, 52, 41-50. [CrossRef]

25. Ray, D.E. Impacts of the 1996 Farm Bill Including Ad Hoc Additions. J. Agric. Appl. Econ. 2001, 33, $245-260$. [CrossRef]

26. Key, N.; Lubowski, R.N.; Roberts, M.J. Farm-level production effects from participation in government commodity programs: Did the 1996 federal agricultural improvement and reform act make a difference? Am. J. Agric. Econ. 2005, 87, 1211-1219. [CrossRef]

27. Wheat Sector at a Glance; ERS: Lausanne, Switzerland, 2019.

28. Davis, W. Wheat Belly: Lose the Wheat, Lose the Weight and Find Your Path Back to Health; Davis W. Weizenwampe-Warum Weizen dick und krank macht: Deutsch, The Netherlands; Wilhelm Goldmann Verlag: München, Germany, 2013.

29. Brouns, F.J.P.H.; van Buul, V.J.; Shewry, P.R. Does wheat make us fat and sick? J. Cereal Sci. 2013, 58, $209-215$. [CrossRef]

30. Giacco, R.; Della Pepa, G.; Luongo, D.; Riccardi, G. Whole grain intake in relation to body weight: From epidemiological evidence to clinical trials. Nutr. Metab. Cardiovasc. Dis. 2011, 21, 901-908. [CrossRef] [PubMed]

31. Koh-Banerjee, P.; Franz, M.; Sampson, L.; Liu, S.; Jacobs, D.R., Jr.; Spiegelman, D.; Willett, W.; Rimm, E. Changes in whole-grain, bran, and cereal fiber consumption in relation to 8-y weight gain among men. Am. J. Clin. Nutr. 2004, 80, 1237-1245. [CrossRef] [PubMed]

32. Clark, I.G. Then Came the Railroads: The Century from Steam to Diesel in the Southwest; University of Oklahoma Press: Norman, OK, USA, 1958.

33. Malin, J.C. Winter Wheat in the Golden Belt of Kansas: A Study in Adaption to Subhumid Geographical Environment; University of Kansas Press: Lawrence, KS, USA, 1944.

34. Dalrymple, D.G. Changes in wheat varieties and yields in the United States, 1919-1984. Agric. Hist. 1988, 62, 20.

35. Clark, J.A.; Ball, C.R.; Martin, J.H. Classification of American Wheat Varieties; US Department of Agriculture: Washington, DC, USA, 1922.

36. USDA. Historical Wheat Varieties; USDA: Washington, DC, USA, 2012.

37. USDA. Annual Wheat Review; Agriculture-NASS, USDA: Oklahoma City, OK, USA, 2018.

38. Thapa, R.; Carver, B.F.; Horn, G.W.; Goad, C.L. Genetic differentiation of winter wheat populations following exposure to two management systems in early inbreeding generations. Crop Sci. 2010, 50, 591-601. [CrossRef]

39. Adams, C.; Thapa, S.B.; Fan, Y.; Park, S. Effects of Two Enhanced-Efficiency Urea Fertilizer Technologies on Agronomic and Economic Performance of Southern Great Plains Winter Wheat. In Proceedings of the ASA, CSSA and SSSA International Annual Meetings, Tampa, FL, USA, 23 October 2017.

40. OSU. Wheat Variety Trial Results; OSU: Stillwater, OK, USA, 2019.

41. Edwards, J.T.; Hunger, R.M.; Smith, E.L.; Horn, G.W.; Chen, M.S.; Yan, L.; Bai, G.; Bowden, R.L.; Klatt, A.R.; Rayas-Duarte, P. ‘Duster'wheat: A durable, dual-purpose cultivar adapted to the southern Great Plains of the USA. J. Plant Registr. 2012, 6, 37-48. [CrossRef] 
42. Prasad, B.; Carver, B.F.; Stone, M.L.; Babar, M.A.; Raun, W.R.; Klatt, A.R. Genetic analysis of indirect selection for winter wheat grain yield using spectral reflectance indices. Crop Sci. 2007, 47, 1416-1425. [CrossRef]

43. Alexander, W.L.; Smith, E.L.; Dhanasobhan, C. A comparison of yield and yield component selection in winter wheat. Euphytica 1984, 33, 953-961. [CrossRef]

44. Khalil, I.H.; Carver, B.F.; Krenzer, E.G.; MacKown, C.T.; Horn, G.W. Genetic trends in winter wheat yield and test weight under dual-purpose and grain-only management systems. Crop Sci. 2002, 42, 710-715.

45. Tyler, J.M.; Webster, J.A.; Merkle, O.G. Designations for Genes in Wheat Germplasm Conferring Greenbug Resistance 1. Crop Sci. 1987, 27, 526-527. [CrossRef]

46. Carver, B.F. Registration of 'Endurance' Wheat. Crop Sci. 2006, 46, 1816-1817. [CrossRef]

47. Chen, M.-S.; Echegaray, E.; Jeffrey Whitworth, R.; Wang, H.; Sloderbeck, P.E.; Knutson, A.; Giles, K.L.; Royer, T.A. Virulence Analysis of Hessian Fly Populations From Texas, Oklahoma, and Kansas. J. Econ. Entomol. 2009, 102, 774-780. [CrossRef] [PubMed]

48. Chen, Y.; Hunger, R.M.; Carver, B.F.; Zhang, H.; Yan, L. Genetic characterization of powdery mildew resistance in US hard winter wheat. Mol. Breed. 2009, 24, 141-152. [CrossRef]

49. Freeman, K.W.; Girma, K.; Teal, R.K.; Arnall, D.B.; Klatt, A.; Raun, W.R. Winter wheat grain yield and grain nitrogen as influenced by bed and conventional planting systems. J. Plant Nutr. 2007, 30, 611-622. [CrossRef]

50. Ratliff, R.L.; Carver, B.F.; Peeper, T.F. Expression of metribuzin sensitivity in winter wheat (Triticum aestivum) populations. Weed Sci. 1991, 39, 130-133. [CrossRef]

51. Weyhrich, R.A.; Carver, B.F.; Smith, E.L. Effect of awn suppression on grain yield and agronomic traits in hard red winter wheat. Crop Sci. 1994, 34, 965-969. [CrossRef]

52. Bai, G.; Das, M.; Carver, B.; Xu, X.; Krenzer, E. Covariation for Microsatellite Marker Alleles Associated with 8 and Coleoptile Length in Winter Wheat. Crop Sci. 2004, 44. [CrossRef]

53. Dahlberg, K.A. The conservation of biological diversity and US agriculture: Goals, institutions, and policies. Agric. Ecosyst. Environ. 1992, 42, 177-193. [CrossRef]

54. Schröder, J.J.; Smit, A.L.; Cordell, D.; Rosemarin, A. Improved phosphorus use efficiency in agriculture: A key requirement for its sustainable use. Chemosphere 2011, 84, 822-831. [CrossRef]

55. Giovannucci, D.; Scherr, S.J.; Nierenberg, D.; Hebebrand, C.; Shapiro, J.; Milder, J.; Wheeler, K. Food and Agriculture: The future of sustainability. Sustain. Dev. 21st Century (SD21) Rep. Rio 2012, 20, 30-54. [CrossRef]

56. Norse, D. Low carbon agriculture: Objectives and policy pathways. Environ. Dev. 2012, 1, 25-39. [CrossRef]

57. Koohafkan, P.; Altieri, M.A.; Gimenez, E.H. Green agriculture: Foundations for biodiverse, resilient and productive agricultural systems. Int. J. Agric. Sustain. 2012, 10, 61-75. [CrossRef]

58. Schonfeld, M.A.; Johnson, R.C.; Carver, B.F.; Mornhinweg, D.W. Water relations in winter wheat as drought resistance indicators. Crop Sci. 1988, 28, 526-531. [CrossRef]

59. Heitholt, J.J.; Croy, L.I.; Maness, N.O.; Nguyen, H.T. Nitrogen partitioning in genotypes of winter wheat differing in grain N concentration. Field Crops Res. 1990, 23, 133-144. [CrossRef]

60. MacKown, C.T.; Carver, B.F. Fall forage biomass and nitrogen composition of winter wheat populations selected from grain-only and dual-purpose environments. Crop Sci. 2005, 45, 322-328. [CrossRef]

61. USDA. United States Standards of Wheat; United State Department of Agriculture-Agricultural Marketing Service, Federal Grain Inspection Service: Washington, DC, USA, 2014.

62. Dougherty, D.A.; Wehling, R.L.; Zeece, M.G.; Partridge, J.E. Evaluation of selected baking quality factors of hard red winter wheat flours by two-dimensional electrophoresis. Cereal Chem. 1990, 67, 546-569.

63. Carver, B.F. Genetic implications of kernel NIR hardness on milling and flour quality in bread wheat. J. Sci. Food Agric. 1994, 65, 125-132. [CrossRef]

64. Carver, B.F.; Krenzer, E.G.; Hunger, R.M.; Martin, T.J.; Klatt, A.R.; Porter, D.R.; Verchot, J.; Rayas-Duarte, P.; Guenzi, A.C.; Martin, B.C.; et al. Registration of 'Intrada' wheat. (Registrations of Cultivars). Crop Sci. 2003, 43, 1135-1136. [CrossRef]

65. Vitale, P.P. Management Practices and Efficiency of Farms in the Western Great Plains. Available online: https://shareok.org/handle/11244/11050 (accessed on 28 January 2020).

66. Burd, J.D.; Porter, D.R. Biotypic Diversity in Greenbug (Hemiptera: Aphididae): Characterizing New Virulence and Host Associations. J. Econ. Entomol. 2006, 99, 959-965. [CrossRef] 
67. Weng, Y.; Perumal, A.; Burd, J.D.; Rudd, J.C. Biotypic diversity in greenbug (Hemiptera: Aphididae): Microsatellite-based regional divergence and host-adapted differentiation. J. Econ. Entomol. 2010, 103, 1454-1463. [CrossRef]

68. Randolph, T.L.; Peairs, F.; Weiland, A.; Rudolph, J.B.; Puterka, G.J. Plant responses to seven Russian wheat aphid (Hemiptera: Aphididae) biotypes found in the United States. J. Econ. Entomol. 2009, 102, 1954-1959. [CrossRef] [PubMed]

69. CSU. Wheat Variety Trial; Colorado State University: Fort Collins, CO, USA, 2011; Available online: https://webdoc.agsci.colostate.edu/csucrops/reports/winterwheat/wheatreport_2011_WFD.pdf (accessed on 28 January 2020).

70. Zhang, X.C.; Nearing, M.A. Impact of climate change on soil erosion, runoff, and wheat productivity in central Oklahoma. CATENA 2005, 61, 185-195. [CrossRef]

71. OSU. Wheat Variety Comparison; Oklahoma State University: Stillwater, OK, USA, 2018.

72. Curtis, B.C.; Rajaram, S.; Gómez, M. Bread Wheat: Improvement and Production; Food and Agriculture Organization of the United Nations (FAO): Rome, Italy, 2002.

73. Pickett, A.A.; Galwey, N.W. A further evaluation of hybrid wheat. Plant Variet. Seeds 1997, 10, 15-32.

74. Jordaan, J.P.; Reynolds, M.P. Hybrid wheat: Advances and challenges. Increas. Yield Pot. Wheat Break. Barriers 1996, 66, 66-75.

75. Cisar, G.; Cooper, D.B.; Curtis, B.C.; Rajaram, S. Hybrid Wheat. Bread Wheat: Improvement and Production; Food and Agriculture Organization: Rome, Italy, 2002; pp. 157-174.

76. Wilson, W.W.; Dahl, B.L. Costs and Risks of Testing and Segregating GM Wheat; North Dakota State University: Fargo, ND, USA, 2002.

77. Wulff, B.B.H.; Dhugga, K.S. Wheat-The cereal abandoned by GM. Science 2018, 361, 451. [CrossRef]

78. Wilson, W.W.; Dahl, B.L.; Jabs, E. Optimal supplier testing and tolerance strategies for genetically modified (GM) wheat. Agric. Econ. 2007, 36, 39-48. [CrossRef]

79. Wilson, W.W.; Janzen, E.L.; Dahl, B.L. Issues in development and adoption of genetically modified (GM) wheats. AgBioForum 2004, 6, 101-112.

80. Kempe, K.; Rubtsova, M.; Gils, M. Split-gene system for hybrid wheat seed production. Proc. Nat. Acad. Sci. USA 2014, 111, 9097-9102. [CrossRef]

81. OFSS. Oklahoma Foundation Seed Stocks Wheat Price List; Oklahoma State University: Stillwater, OK, USA, 2019.

82. Fernandez-Cornejo, J. The Seed Industry in U.S Agriculture-An Exploration of Data and Information on Crop Seed Markets, Regulation, Industry Structure, and Research and Development; USDA-ERS: Washington, DC, USA, 2004.

83. Barkley, A.P. Kansas Wheat Breeding: An Economic Analysis; Kansas State University: Manhattan, KS, USA, 1997.

84. USWA. Weekly Price Report; United States Wheat Associate: Washington, DC, USA, 2019.

85. OSU. Protein Content of Winter Wheat Varieties in Oklahoma-2016-2017; Oklahoma State University: Stillwater, OK, USA, 2018.

86. Terman, G.L. Yields and Protein Content of Wheat Grain as Affected by Cultivar, N, and Environmental Growth Factors 1. Agron. J. 1979, 71, 437-440. [CrossRef]

87. Guthrie, D.A.; Smith, E.L.; McNew, R.W. Selection for High and Low Grain Protein in Six Winter Wheat Crosses 1. Crop Sci. 1984, 24, 1097-1100. [CrossRef]

88. Carver, B.F.; Khalil, I.; Krenzer, E.G.; MacKown, C.T. Breeding winter wheat for a dual-purpose management system. Euphytica 2001, 119, 231-234. [CrossRef]

89. OSU. Genetic Improvement of Winter Wheat: Integrating Classical and Novel Approaches, Research Proposal for OWRF and OWC FY 2017-2018; Oklahoma State University: Stillwater, OK, USA, 2019.

(C) 2020 by the authors. Licensee MDPI, Basel, Switzerland. This article is an open access article distributed under the terms and conditions of the Creative Commons Attribution (CC BY) license (http://creativecommons.org/licenses/by/4.0/). 